\title{
Standardization of Seed and Vegetative Propagation Techniques in Saraca asoca (Roxb.) De Wilde: An Endangered Medicinal Plant
}

\author{
S.I. Madhushree ${ }^{1 *}$, G. Raviraja Shetty ${ }^{1}$, K. Souravi ${ }^{2}$, P.E. Rajasekharan ${ }^{2}$, \\ M. Ganapathi ${ }^{1}$ and C.S. Ravi ${ }^{1}$
}

${ }^{1}$ Department of Plantation, Spices, Medicinal and Aromatic Crops, College of Horticulture, Mudigere-577132, University of Agricultural and Horticultural Sciences, Shivamogga, India

${ }^{2}$ Division of Plant Genetic Resources, ICAR-Indian Institute of Horticultural Research, Bengaluru-560089, Karnataka, India

*Corresponding author

\begin{tabular}{|c|c|}
\hline & B S T R A C T \\
\hline Keywords & \multirow{3}{*}{$\begin{array}{l}\text { Saraca asoca (Roxb.) De Wilde is one of the endangered medicinal plants of Western } \\
\text { Ghats. An experiment was carried out to standardize seed and vegetative propagation for } \\
\text { this very important medicinal plant. Among the different germination inducing treatments, } \\
\text { the seed treated with } \mathrm{GA}_{3} 200 \mathrm{ppm} \text { recorded early germination }(23.73) \text {, highest } \\
\text { germination rate }(2.95 \%) \text {, seedling vigour }(6315.10) \text {, seedling height }(68.40 \mathrm{~cm}) \text {, fresh } \\
\text { weight }(16.00 \mathrm{~g}) \text { and dry weight of seedling }(8.47 \mathrm{~g}) \text {. In case of vegetative propagation, } \\
\text { hard wood cuttings and air layering was carried out. Cuttings treated with IBA2000 ppm } \\
\text { had a significant positive effect on the percentage of rooting }(33.41) \text {, sprouting }(33.70) \text { and } \\
\text { number of days taken for sprouting }(23.00) \text {. In air layering branches treated with IBA } 2500 \\
\text { ppm had a significant influence on rooting ( } 88.07 \%) \text { number of days taken for root } \\
\text { initiation ( } 32.00) \text {, root diameter }(3.53 \mathrm{~mm}) \text {, number of primary roots per layer }(6.00) \text {, } \\
\text { number of secondary roots per layer }(40.17) \text { and root length }(13.03 \mathrm{~cm}) \text {. Results will be } \\
\text { highly useful for large scale for large scale multiplication of the plant. }\end{array}$} \\
\hline Article Info & \\
\hline & \\
\hline
\end{tabular}

\section{Introduction}

Saraca asoca (Roxb.) De Wilde is commonly known as Sita-Ashoka or Sorrow less tree. It is an important evergreen sacred tree where bark, flowers and seeds are medicinally important. S. asoca is a red listed species which belongs to the family Caesalpiniaceae (Bhalerao et al., 2014). It is distributed throughout India, predominantly in southern India (Western Ghats of Karnataka, Kerala and Andhra Pradesh), Odisha and Assam, and up to an altitude of $750 \mathrm{~m}$ above sea level in the Central and Eastern Himalaya (Patwardhan et al., 2016).

It is one of the important plants of Indian system of medicine known for its variety of pharmacological activities and listed under 32 priority species of National Medicinal Plant Board (NMPB). There are several vernacular names of $S$. asoca in different languages. It is called as Kankeli in Sanskrit; Ashoka in English; Asokam in Malayalam; Vandichitrah 
in Hindi; Kenkali mara, Ashokada mara in Kannada and Asogam in Tamil (Pradhan et al., 2009).

S. asoca is one of the foremost plants utilized from antiquity till to date. It has high medicinal value and is used in many Ayurvedic drugs. Ayurvedic medicine manufacturers across the country use about 2,250 tons of bark and flower annually. Hindus regard this tree as highly sacred and termed as symbol of fertility. Bark is used in treatment of genitor-urinary problems, enlargement of cervical gland, thrust burning sensation, dyspepsia, piles, ulcers, menorrhagia, leucorrhoea, pimples, intestinal worms and animal poisoning (Ankur, 2015). The famous compound preparations are Ashokaristha and Ashokaghrita (Jadhav and Bhutani, 2005).

\section{Materials and Methods}

\section{Location}

The experiment was conducted during the year 2016-17 at College of Horticulture, Mudigere, Department of Plantation spices, Medicinal and Aromatic Crops and ICAR-Indian Institute of Horticultural Research, Division of Plant Genetic Resources, Hessaraghatta, Bengaluru.

\section{Planting material}

The required planting materials were collected from Indian Institute of Horticultural Research (IIHR), Bengaluru. The collected seeds were treated with mercuric chloride $(0.1 \%)$ for 10 minutes, washed with water and shade dried. Seeds are subjected to 11 different pre-soaking treatments in three replications and complete randomized design was followed. In vegetative propagation stem cuttings and airlayering was done. Stem cuttings were prepared by taking the middle portion of the stem with a length of $15.00-20.00 \mathrm{~cm}$ without any branches and leaves with 2-3 nodes per cutting and uniform thickness. The basal portion of the cutting was given a slant cut and lower node of the cutting was planted in the polybag. Cuttings were treated with 13 different growth regulators in three replications and complete randomized design was followed. The experiment was carried out in polyhouse under partial shade condition (50\% shade). This structure helps in maintaining the higher temperature and relative humidity (An average temperature of $29^{\circ} \mathrm{C}$; relative humidity of $75 \%$ and light intensity of 3500 lux was recorded inside the poly house during the period of experimentation), which in turn increases seed germination and also increases rooting in the cuttings. The data were analysed statistically as per the method suggested by Panse and Sukhatme (1985).

In air layering healthy, well matured uniform with vigorous growth mother plants were selected. On these plants previous year growth matured shoots of about pencil thickness were selected at random for air layering. Air layering was done by girdling the pencil thickness shoots of one year, about 25.00 to $30.00 \mathrm{~cm}$ from the top of the shoot. A complete ring with $2.50 \mathrm{~cm}$ width strip of bark was removed by making two cuts. The continuity of cambial layer was disrupted by gently rubbing of exposed wood portion, the required concentration of growth regulators were smeared on girdled portion of stem with soft cotton, as per the treatments then dried for few seconds.

The girdled portion was covered with sterilized moist sphagnum moss and coco peat and secured firmly with a polythene sheet and both the ends were tied firmly using thread in field. Air layered branches were treated with 13 different growth regulators in three replications and randomized complete block 
design was followed. The data were analysed statistically as per the method suggested by Panse and Sukhatme (1985).

\section{Results and Discussion}

The data pertaining to various germination and growth parameters as influenced by different growth regulators for seed propagation of $S$. asoca are presented in Table 1 .

There was significant influence of treatments on germination and growth parameters such as days to initiate germination, rate of germination, germination percentage, seedling vigour, seedling height $(\mathrm{cm})$, fresh weight $(\mathrm{g})$ and dry weight of seedling $(\mathrm{g})$. The growth regulator treatment increased the overall germination and growth parameter values as compared to control. Significantly minimum days to initiate germination (23.73), rate of germination (2.95) and germination percentage (92.33) was registered in $\mathrm{GA}_{3} 200 \mathrm{ppm}$ which was followed by $\mathrm{GA}_{3} 100$ ppm (Table 1).

This may be due to instigative action of $\mathrm{GA}_{3}$ for germination of seeds. $\mathrm{GA}_{3}$ induces the denovo synthesis of proteolytic enzymes like aamylase and ribonuclease. Amylases in turn hydrolyse starch in the endosperm, providing the essential sugars for the initiation of growth processes (Copeland and Mc-Donald, 1995). $\mathrm{GA}_{3}$ treatment is also known to overrule the photo dormancy, thermo-dormancy, dormancy imposed by incomplete embryo development, mechanical barriers and presence of germination inhibitors (Diaz and Martin, 1971).

Among different growth regulator treatments maximum seedling vigour (6315.10), seedling height $(68.40 \mathrm{~cm})$, fresh weight $(16.00 \mathrm{~g})$ and dry weight $(8.47 \mathrm{~g})$ of seedling was also recorded in seeds treated with $\mathrm{GA}_{3}$ 200ppm when compared to control (Table 1). Similar results were also obtained by Masoodi and Masoodi (2000) for Ulmus wallichiana, an endangered tree species. This is also due to the effect of gibberellic acid in inducing the formation of hydrolytic enzymes which in turn might have increased carbohydrates accumulation thereby increasing the fresh weight and dry weight of plant (Bhattacharjee et al., 1994).

Lalithkumar (2008) obtained higher germination per cent of 77. 9, 74. 9, 82. 0 and 71. 0 per cent against control (51. 0, 43. 0, 38 . 0 and 31. 9 per cent), in tulsi, ashwagandha, periwinkle and kalmegh, respectively, when the seeds were treated with $\mathrm{GA}_{3}$ at $250 \mathrm{ppm}$. This may be due to GA3 role in cell division and cell enlargement and are largely controlled by endogenous level of gibberellic acid which has been proved in number of crops. The increased cell division and cell elongation reflected in increased plant height was observed in hybrid lilies (Gorden et al., 1980).

The data pertaining to various growth parameters as influenced by different growth regulators for cuttings propagation of $S$. asoca are presented in Table 2 .

There was significant influence of different treatments on parameters such as days taken for sprouting of stem cuttings, number of sprouts per cutting, sprouting and rooting percentage.

Cuttings treated with IBA showed good results for all the parameters as compared to control. It is well known that auxins are associated with the division and elongation of meristematic cells and has been attributed to enhanced transport of carbohydrates to the base of the cuttings and also increase the activity of hydrolyzing enzymes and there by consequently stimulate rooting (Ali et al., 2008). 

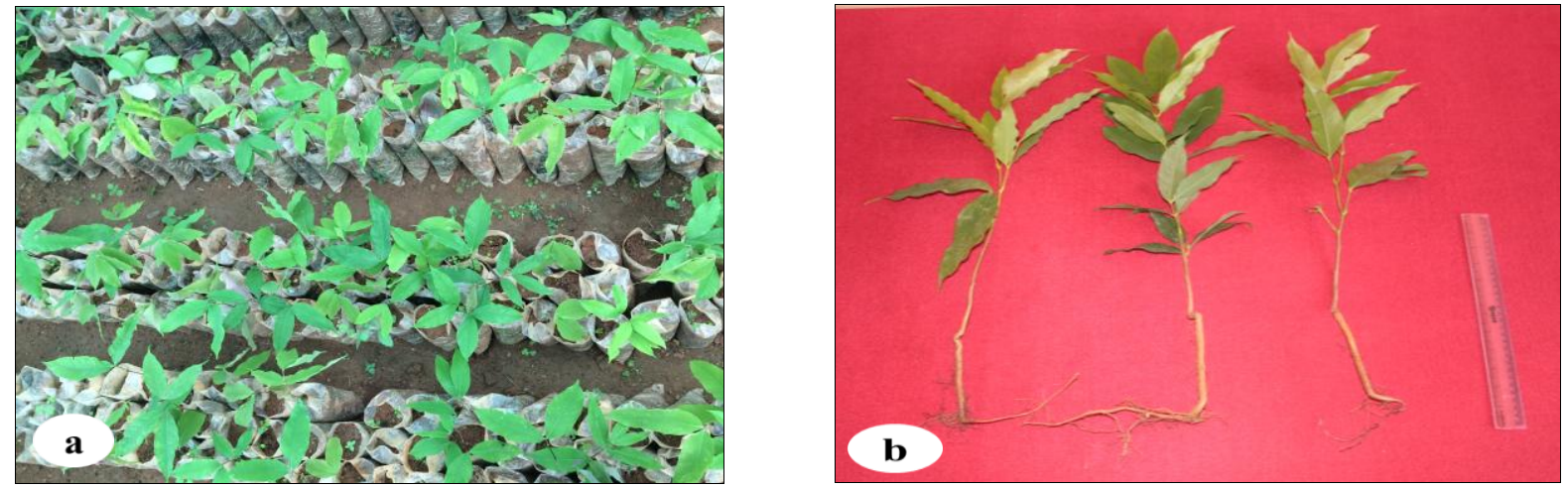

Fig.1 Best treatment for germination of Saraca asoca seeds (a. Early germination in $\mathrm{GA}_{3} 200$ ppm b. $\mathrm{GA}_{3} 200$ ppm treated seedlings at 120 DAS)
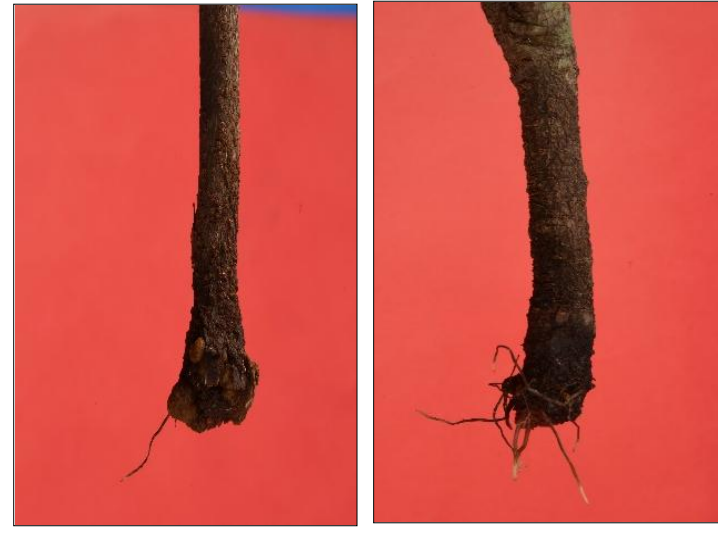

Fig.2a Root initiation in Saraca asoca cuttings
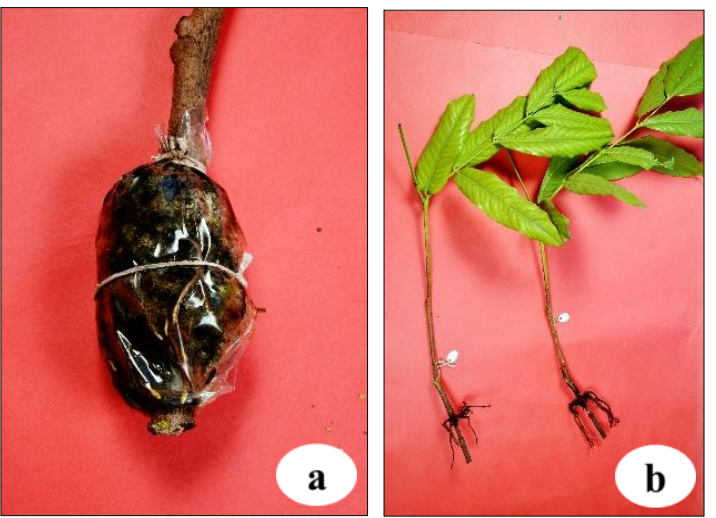

Fig.3a a. Root initiation in air layers b. Effect of IBA 2500 ppm on rooting of Saraca asoca air layers at 45 days

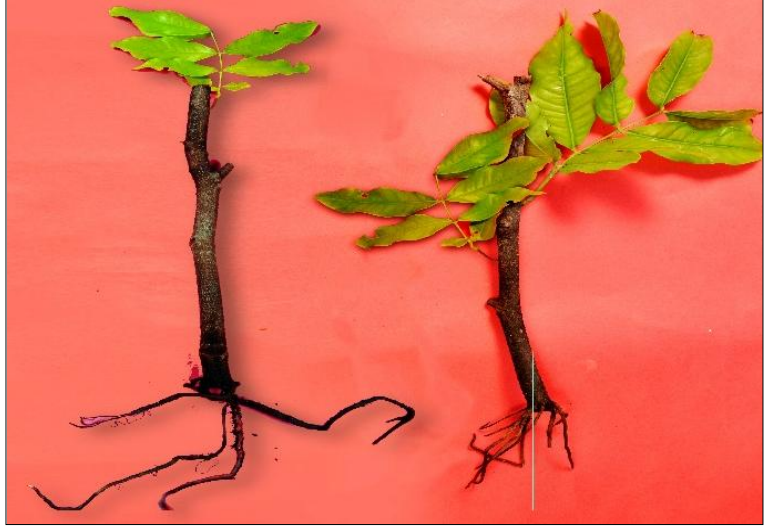

Fig.2b Effect of IBA 2000 ppm on sprouting and rooting of Saraca

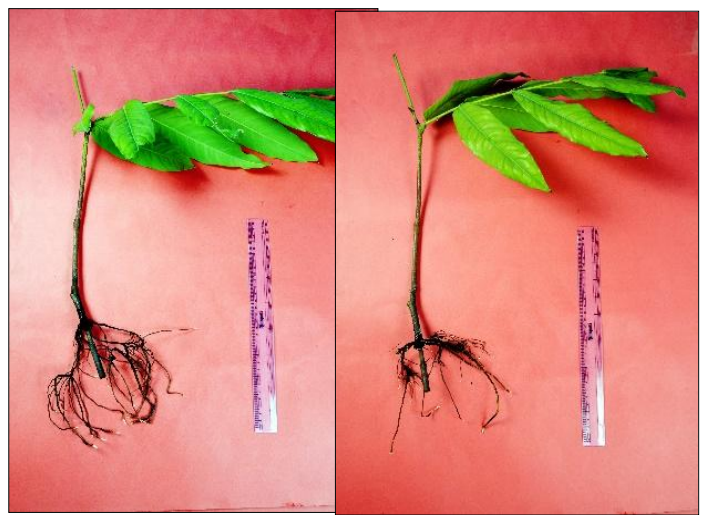

Fig.3b Effect of IBA 2500 ppm on rooting of Saraca asocaair layers at 60 days 
Table.1 Effect of different pre sowing treatments on growth parameters as influenced in Saraca asoca (Roxb.) De Wilde seeds

\begin{tabular}{|c|c|c|c|c|c|c|c|}
\hline Treatment & $\begin{array}{c}\text { Days to } \\
\text { initiate } \\
\text { germination }\end{array}$ & $\begin{array}{c}\text { Rate of } \\
\text { germination } \\
(\%)\end{array}$ & $\begin{array}{c}\text { Germination } \\
\qquad(\%)\end{array}$ & $\begin{array}{c}\text { Seedling } \\
\text { height } \\
\text { (cm) }\end{array}$ & $\begin{array}{l}\text { Seedling } \\
\text { vigour }\end{array}$ & $\begin{array}{l}\text { Fresh weight } \\
\text { of seedling } \\
\text { (g) }\end{array}$ & $\begin{array}{c}\text { Dry weight } \\
\text { of seedling } \\
\text { (g) }\end{array}$ \\
\hline $\mathrm{T}_{1}-$ Control & 56.60 & 0.60 & $43.44(41.23)$ & 38.20 & 1659.43 & 4.13 & 1.86 \\
\hline $\mathrm{T}_{2}-\mathrm{GA}_{3} 100 \mathrm{ppm}$ & 25.13 & 2.63 & $90.11(71.66)$ & 63.26 & 5700.13 & 14.20 & 7.10 \\
\hline$T_{3}-G_{3} 200$ ppm & 23.73 & 2.95 & 92.33 (73.92) & 68.40 & 6315.10 & 16.00 & 8.47 \\
\hline $\mathrm{T}_{4}-\mathrm{KNO}_{3} 0.5 \%$ & 52.47 & 1.05 & $58.00(49.60)$ & 42.86 & 2485.57 & 5.67 & 2.83 \\
\hline $\mathrm{T}_{5}-\mathrm{KNO}_{3} 1.0 \%$ & 48.93 & 1.26 & $63.22(52.66)$ & 46.48 & 2938.20 & 6.80 & 3.26 \\
\hline $\mathrm{T}_{6}-\mathrm{H}_{2} \mathrm{SO}_{4} 1.0 \%$ & 38.40 & 2.06 & $83.00(65.66)$ & 54.23 & 4501.17 & 11.00 & 5.50 \\
\hline $\mathrm{T}_{7}-\mathrm{H}_{2} \mathrm{SO}_{4} 2.0 \%$ & 36.20 & 2.27 & $85.22(67.38)$ & 57.37 & 4888.60 & 12.13 & 6.35 \\
\hline $\mathrm{T}_{8}-\mathrm{HCl} 1.0 \%$ & 39.40 & 1.51 & $76.44(60.96)$ & 49.87 & 3811.67 & 8.70 & 4.36 \\
\hline $\mathrm{T}_{9}-\mathrm{HCl} 2.0 \%$ & 37.13 & 1.88 & $80.56(63.84)$ & 52.30 & 3997.70 & 10.27 & 5.10 \\
\hline $\begin{array}{l}T_{10}-\text { Ascorbic acid } \\
500 \text { ppm }\end{array}$ & 42.00 & 1.47 & $72.74(58.52)$ & 49.20 & 3578.57 & 8.27 & 3.94 \\
\hline $\begin{array}{l}T_{11}-\text { Ascorbic acid } \\
1000 \text { ppm }\end{array}$ & 40.40 & 1.71 & $78.00(62.04)$ & 52.36 & 4083.53 & 9.90 & 4.93 \\
\hline Mean & 40.04 & 1.76 & $74.82(59.66)$ & 52.23 & 3996.33 & 9.73 & 4.88 \\
\hline S. Em \pm & 0.22 & 0.04 & 0.45 & 0.42 & 17.37 & 0.21 & 0.13 \\
\hline CD@ 5\% & 0.63 & 0.11 & 1.32 & 1.22 & 50.95 & 0.62 & 0.39 \\
\hline
\end{tabular}


Table.2 Effect of different growth regulator treatments on growth parameters as influenced in Saraca asoca (Roxb.) De Wilde cuttings

\begin{tabular}{|c|c|c|c|c|}
\hline Treatment & $\begin{array}{l}\text { Days taken for } \\
\text { sprouting of stem } \\
\text { cuttings }\end{array}$ & $\begin{array}{l}\text { Number of sprouts } \\
\text { per cutting }\end{array}$ & $\begin{array}{l}\text { Sprouting } \\
\text { percentage }\end{array}$ & $\begin{array}{c}\text { Rooting } \\
\text { percentage }\end{array}$ \\
\hline $\mathrm{T}_{1}$-Control & 0.00 & 0.00 & $0.00(0.46)$ & $0.00(0.46)$ \\
\hline $\mathrm{T}_{2}-\mathrm{IBA} 250 \mathrm{ppm}$ & 28.33 & 0.83 & $20.43(26.90)$ & $17.30(24.60)$ \\
\hline $\mathrm{T}_{3}-$ IBA $500 \mathrm{ppm}$ & 26.67 & 1.00 & $23.30(28.90)$ & $20.27(26.80)$ \\
\hline $\mathrm{T}_{4}-$ IBA 1000 ppm & 26.00 & 1.16 & $26.10(30.70)$ & $24.29(29.50)$ \\
\hline $\mathrm{T}_{5-}$ IBA $1500 \mathrm{ppm}$ & 25.33 & 1.16 & $30.06(33.20)$ & $29.04(32.60)$ \\
\hline$T_{6}-$ IBA 2000 ppm & 23.00 & 1.33 & $33.70(35.50)$ & $33.41(35.30)$ \\
\hline T $_{7-}$ NAA 50 ppm & 0.00 & 0.00 & $0.00(0.46)$ & $0.00(0.46)$ \\
\hline T8 & 0.00 & 0.00 & $0.00(0.46)$ & $0.00(0.46)$ \\
\hline T9_ NAA 150 ppm & 0.00 & 0.00 & $0.00(0.46)$ & $0.00(0.46)$ \\
\hline T $_{10-N A A} 200$ ppm & 0.00 & 0.00 & $0.00(0.46)$ & $0.00(0.46)$ \\
\hline 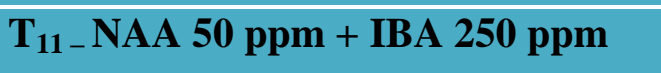 & 31.00 & 0.66 & $18.73(25.60)$ & $14.20(22.10)$ \\
\hline T $_{12}$ NAA 100 ppm + IBA 500 ppm & 28.00 & 0.83 & $21.70(27.80)$ & $16.24(23.80)$ \\
\hline $\mathrm{T}_{13-\mathrm{NAA}} 150$ ppm + IBA 1000 ppm & 26.33 & 1.00 & $24.33(29.60)$ & $22.25(28.10)$ \\
\hline Mean & 16.51 & 0.61 & $15.26(23.20)$ & $13.62(21.80)$ \\
\hline S. Em \pm & 0.29 & 0.12 & 0.49 & 0.55 \\
\hline CD@5\% & 0.85 & 0.36 & 1.43 & 1.59 \\
\hline
\end{tabular}


Table.3 Effect of different growth regulator treatments on growth parameters as influenced in Saraca asoca (Roxb.) De Wilde air layering

\begin{tabular}{|c|c|c|c|c|c|c|}
\hline Treatment & $\begin{array}{c}\text { Days taken } \\
\text { for root } \\
\text { initiation }\end{array}$ & $\begin{array}{c}\text { Rooting } \\
\text { percentage }\end{array}$ & $\begin{array}{c}\text { Root } \\
\text { diameter } \\
(\mathbf{m m})\end{array}$ & $\begin{array}{c}\text { Number of } \\
\text { primary } \\
\text { roots }\end{array}$ & $\begin{array}{l}\text { Number of } \\
\text { secondary } \\
\text { roots }\end{array}$ & Root length \\
\hline $\mathrm{T}_{1}$-Control & 40.33 & $64.40(53.36)$ & 2.17 & 1.64 & 13.57 & 5.17 \\
\hline $\mathrm{T}_{2}-\mathrm{IBA} 500$ ppm & 36.67 & $81.33(64.43)$ & 2.73 & 3.30 & 24.10 & 9.23 \\
\hline $\mathrm{T}_{3}-\mathrm{IBA} 1000 \mathrm{ppm}$ & 34.40 & $84.67(66.96)$ & 3.07 & 4.50 & 26.40 & 11.42 \\
\hline $\mathrm{T}_{4}-\mathrm{IBA} 1500 \mathrm{ppm}$ & 34.77 & $85.27(67.45)$ & 3.09 & 4.83 & 27.60 & 11.60 \\
\hline $\mathrm{T}_{5-}$ IBA $2000 \mathrm{ppm}$ & 33.33 & $86.03(68.02)$ & 3.17 & 5.43 & 32.07 & 12.10 \\
\hline $\mathrm{T}_{6}-$ IBA $2500 \mathrm{ppm}$ & 32.00 & $88.07(69.81)$ & 3.53 & 6.00 & 40.17 & 13.03 \\
\hline $\mathrm{T}_{7-}$ IBA 3000 ppm & 33.83 & $85.57(67.68)$ & 3.10 & 4.90 & 28.27 & 11.73 \\
\hline T 8 $_{-}$NAA 100 ppm & 38.50 & $73.03(58.72)$ & 2.48 & 2.53 & 19.20 & 7.67 \\
\hline$T_{9-}$ NAA 200 ppm & 38.27 & $76.20(60.81)$ & 2.62 & 2.72 & 22.13 & 8.53 \\
\hline $\mathrm{T}_{10}$ NAA 300 ppm & 39.07 & $71.33(57.63)$ & 2.43 & 2.23 & 17.50 & 7.37 \\
\hline $\begin{array}{l}\text { T11 - NAA } 100 \text { ppm + IBA } 2000 \\
\text { ppm }\end{array}$ & 35.30 & $82.20(65.04)$ & 2.94 & 3.92 & 26.27 & 10.17 \\
\hline $\begin{array}{l}\text { T } \\
\text { ppm }\end{array}$ & 34.93 & $84.33(66.70)$ & 3.06 & 4.33 & 27.10 & 11.20 \\
\hline $\begin{array}{l}\text { T }_{13-} \text { NAA } 300 \text { ppm + IBA } 3000 \\
\text { ppm }\end{array}$ & 36.30 & $81.60(64.61)$ & 2.82 & 3.60 & 25.00 & 9.47 \\
\hline Mean & 35.98 & $80.31(63.55)$ & 2.86 & 3.84 & 25.34 & 9.90 \\
\hline S. Em \pm & 0.23 & 0.72 & 0.10 & 0.19 & 0.70 & 0.36 \\
\hline CD@5\% & 0.68 & 2.10 & 0.30 & 0.55 & 2.05 & 1.06 \\
\hline
\end{tabular}


Parameters like number of days taken for sprouting (23.00), number of sprouts per cutting (1.33), sprouting (33.70\%) and rooting (33.41\%) was also found to be maximum in cuttings treated with IBA 2000 ppm. Similar results were obtained in Embelia tsjeramcottam cuttings treated with IBA 2000 ppm and there was significant increase in rooting percentage $(42.00 \%)$ and sprouting percentage $(35.80 \%)$ against the control (Sharma et al., 2010). Yashaswini et al., (2011) reported that a rare medicinal plant species Premna integrifolia propagated by hard wood cuttings showed higher rooting percentage $(86.00 \%)$ when cuttings treated with 2000 ppm IBA against control (57.66\%).Husen (2003) reported that Rauvolfia serpentine cuttings treated with IBA 2000 ppm showed significant increase in rooting and sprouting percentage against the control. Nanda and Kochar (1985) found that some group of plants including most fruit and nut species and many woody plant rich in tannins and phenolic compounds are difficult to propagate by cuttings because of poor rooting and the same was true even in case of S. asoca.

The data pertaining to various rooting parameters as influenced by different growth regulators for air layering propagation of $S$. asoca are presented in Table 3.

Parameters like rooting $(88.07 \%)$ number of days taken for root initiation (32.00), root diameter $(3.53 \mathrm{~mm})$, number of primary roots per layer (6.00), number of secondary roots per layer $(40.17)$, root length $(13.03 \mathrm{~cm})$ was found to be maximum in air layers treated with IBA $2500 \mathrm{ppm}$. Similar results were obtained in litchi air layers treated with 2500 ppm of IBA showed maximum number of roots $(9.94)$, root length $(10.94 \mathrm{~cm})$, number of leaves (10.55) when compared to control (Rahman et al., 2000). Good success on rooting and root characteristics of air layering in Chebulic mycobalum has been recorded by Misra and Jaiswal (1994) after treatments with IBA. IBA has been found to stimulate root initiation in air layers of many plant species like Carissa carandas and Dalbergia sissoo (Puri and Nagpal, 1988). Kunal and Syamal (2005) reported that shoots treated with IBA 3000 ppm influenced maximum number of primary roots (14.80), number of secondary roots (10.72), length of the primary root $(11.30 \mathrm{~cm})$, diameter of the roots $(2.20$ $\mathrm{mm})$, rooting $(93.34 \%)$ and survival percentage of air layers in guava (75.90) followed by NAA at 2000 ppm and lest was observed in control.

The results presented in the paper constitute the study on seed and vegetative propagation of Saraca asoca by cuttings and air layering. The success of germination in seed $(90 \%)$ and among vegetative propagation, rooting success of cuttings was very meagre, however, air layering was best over cuttings by producing $(88.07 \%)$ rooting.

\section{References}

Ali, M., Malik, A. R. and Sharma, K. R. (2008). Vegetative propagation of Berberis aristata DC. An endangered Himalayan shrub. J. Med. Plant Res. 2: 374-377.

Ankur, V. (2015). Micro propagation of Saraca asoca (Roxb.) De Wilde in response to biochemical and seasonal variations. Ph.D thesis, Forest Research Institute University, Dehradun, Uttarakhand (India). Pp. 217.

Bhalerao, S. A., Verma, D. R., Didwana, V. S. and Teli, N. C. (2014). Saraca asoca (Roxb.), De. Wild: An overview. Ann. Plant Sci.3: 770-775.

Bhattacharjee, S. K., Mukherjee, T. and Yadev, L. P. (1994). Standardization of agro-tech in tuberose. Indian Perfumer, 38: 144-152. 
Copeland, L. O. and Mc-donald, M. B. (1995). Principles of Seed Science and Technology. III Edition. Chapman and Hall Publications, New York, pp. 127146.

Diaz, D. H. and Martin, G. C. (1971). Peach seed dormancy in relation to inhibitors and applied growth substance. $J$. American Soc. Hort. Sci.97: 651-654.

Gorden, R. H. and Roger, M. (1980). An evaluation of new growth retardants on mid-century hybrid lilies. Scientia Hort. 13: 349-359.

Husen, A. (2003). Effects of IBA and NAA treatments on rooting of Rauvolfia serpentine Benth. Ex Kurz shoot cuttings. Ann. For.11: 88-93.

Jadhav, A.N. and Bhutani, K.K. (2005). Ayurveda and gynecological disorders, Journal of Ethnopharmacology97: 151159.

Kunal, K. and Syamal, M. M. (2005). Effect of etiolation and plant growth substances on rooting of air-layers in guava. Indian J. Hort. 62: 290:292.

Lalithkumar, B. V. B. (2008). Standardization of seed testing procedures and storage studies in selected medicinal crops. M.Sc. (Agri.) Thesis, Univ. Agric. Sci., Dharwad (India).

Masoodi, T. H. and Masoodi, N. A. (2000) Germination and growth behaviour of endangered multipurpose tree speciesUlmus wallichiana. Ann. For.8: 45-52.

Misra, K. K. and Jaiswal, H. R. (1994). Effects of growth regulators on rooting and survival of air layers of Karonda (Carissa carandas L.). Ann. Agric. Res.11: 208-210.
Nanda, K. K. and Kochar, V. K. (1985). Vegetative propagation of plants. Kalyani publishers, New Delhi, India.

Panse, V. G. and Sukhatme, P. V. (1985). Statistical Methods for Agricultural Workers, ICAR, New Delhi, p.381.

Patwardhan, A., Pimputkar, M., Mahaskar, M., Agarwal, P., Barve, N., Gunaga, R. and Mirgal, A. (2016). Distribution and population status of threatened medicinal tree Saraca asoca (Roxb.) De Wilde from Sahyadri-Konkan ecological corridor. Curr. Sci. 111: 1500-1506.

Pradhan, P., Joseph, L., Gupta, V., Chulet, R., Arya, H., Verma, R. and Bajpai, A. (2009). Saraca asoca (Ashoka): A Review. J. Chem. Pharm. Res.1: 62-71.

Puri, S. and Nagpal, R. (1988). Effects of auxins on air layers of some agroforestry species. Indian J. For.11: 28-32.

Rahman, N., Hussain, I., Mohammod, I. M. J. and Azmat, A. A. (2000). Effect of different concentrations of IBA on rooting of litchi (Litchi chinensis) in airlayering. Pakistan J. Biol. Sci. 3: 330331.

Sharma, Y., Venugopal, C. K., Vasudeva, R., Manjunath, A. V. and Yashwant, K. (2010). Propagation of a rare medicinal plant species Embelia tsjeram-cottam by root cuttings. Asian J. Hort.5: 383387.

Yashaswini, S., Venugopal, C. K. and Hegde, R. V. (2011). Propagation of rare medicinal plant species Premna integrifolia by hardwood cuttings. Indian J. Hort. 68: 108-112.

\section{How to cite this article:}

Madhushree, S.I., G. Raviraja Shetty, K. Souravi, P. E. Rajasekharan, M. Ganapathi and Ravi, C.S. 2018. Standardization of Seed and Vegetative Propagation Techniques in Saraca asoca (Roxb.) De Wilde: An Endangered Medicinal Plant. Int.J.Curr.Microbiol.App.Sci. 7(04): 13271335. doi: https://doi.org/10.20546/ijcmas.2018.704.148 